\title{
Government's Mass Mobilization in Administrative Reforms in Ho Chi Minh City Today
}

\author{
Ngoc Loi Pham \\ Ho Chi Minh City Cadre Academy, Ho Chi Minh City, Vietnam
}

Email address:

phamngocloi728@gmail.com

\section{To cite this article:}

Ngoc Loi Pham. Government's Mass Mobilization in Administrative Reforms in Ho Chi Minh City Today. American Journal of Applied Psychology. Vol. 10, No. 1, 2021, pp. 27-33. doi: 10.11648/j.ajap.20211001.15

Received: February 12, 2021; Accepted: March 1, 2021; Published: March 10, 2021

\begin{abstract}
In this study, the author aims to explore the views, theories as well as practical issues about mass mobilization work in administrative reforms in the districts of Ho Chi Minh City. The author has proposed two hypotheses: Firstly, the awareness of the government's mass mobilization of the districts in administrative reforms is a long-term and continuous process to improve the efficiency of organizations and improve the regime and administrative modes. Secondly, mass mobilization activities of the districts in administrative reforms have gained achievements and raised issues need to be addressed to improve administrative reforms of the districts to serve the lives of the people better. In this study, the author has used scientific research methods such as analysis and synthesis, interpretation and induction, generalization, logic, history, and comparison to come to the general conclusions on the government's mass mobilization of the district authorities in administrative reforms in Ho Chi Minh city. The study has carried out in districts of Ho Chi Minh city. It has found that the government's mass mobilization of the districts in Ho Chi Minh city contributed to the awareness of officials as well as the people about the city's administrative reforms, meeting the people's desire. It plays a very important part in the implementation of administrative procedure reforms; publicity and transparency of guidelines and policies; socio-economic development programs and projects in districts, revenues and expenditures from the budget and other sources. The author suggested that the government should promote mass mobilization work in administrative reforms across the country.
\end{abstract}

Keywords: Government's Mass Mobilization Work, Administrative Reform, Ho Chi Minh City

\section{Introduction}

The state administrative system is always in the "dynamic" process, ensuring the state management in social fields and finding ways to respond to changes in society and the economy. There comes a time if there are no changes in the public administration, administrative reforms will become a hindrance, making the effectiveness and efficiency of the state administration less effective. That is when the administration needs to be reformed in a master plan or some inadequate factors.

Currently, the request for reforms of state administrative agencies in Vietnam is raised very early. Starting from the renovation period, administrative reforms are more urgent. In the current renovation, the entire Party, people, and army are striving to successfully realize the renovation objectives and tasks: building a socialist-oriented market economy; promoting industrialization and modernization of the country; building a rule of law state of the people, by the people and for the people to successfully build socialism in our country. This is a herculean, and completely new goal and task, implemented in favorable conditions, but it is also facing many difficulties and challenges. The hostile forces have intensified the destruction of our people's renewal cause under the leadership of the Party and the management of our State. That fact requires strengthening the leadership and renewing mass mobilization work in general and in authorities at all levels in particular, to mobilize the people to successfully realize those goals and tasks. The government's mass mobilization in the current period plays a more important role in administrative reforms to serve the people.

Therefore, this study aims to explore the role of the government's mass mobilization work in the implementation of administrative procedure reforms; publicity and transparency of guidelines and policies; socio-economic development programs and projects in districts; revenues and 
expenditures from the budget and other sources.

\section{Literature Review}

\subsection{Previous Studies}

Administrative reforms are a long-term and continuous process to improve organizational performance, old administrative regimes and modes in the management scope of many organizations or an organizational system. Administrative reforms are changes intentionally designed to improve fundamentally organizational divisions and management activities such as planning, institutions, organizational apparatus, personnel work, financial management, command, coordination, inspection, information, and evaluation [1]. The United Nations (1971) view that administrative reforms are intentional attempts to induce fundamental changes in the public administration system through systematic reforms or change methods to improve at least one of the constituent elements of the state administration: institutions, organizational structures, human resources, public finance, and the management process [2].

The resolution of the 6th National Party Congress on the comprehensive national renewal of the country and the organization of the state apparatus has been restructured in a simple manner. The Communist Party of Vietnam has proposed a policy of "implementing major reforms of the organizational structure of state agencies" [3]. That is an important political premise for administrative reforms. The 7th National Party Congress (1991) adopted the National Construction Platform in the Transitional period to Socialism, defining the focus of state agency reforms as "targeting the administrative system with the focus is to build a smooth administrative system and state administrative management with enough power, capacity and efficiency". The 8th National Party Congress (1996) continued to mention the requirements of implementing administrative reforms synchronously, based on the law, considering them as a basic solution to perform the tasks and major objectives of the socio-economic development plan [4]. Emphasizing the task of accelerating administrative procedure reforms and restructuring the administrative agencies from the central to local levels. The 9th National Party Congress with the adoption of the National Construction Platform in the Transitional Period to Socialism (supplemented and developed in 2011) proposed the task of building a uniform administration as the most transparent, clean, strong, effective streamlined organization; increasing democracy and the rule of law in government administration [5]. The 7th National Party Congress (2016) requested: Promoting the implementation of the Master Program on state administrative reforms by building a democratic, modern, professional and dynamic administration to effectively serve the people [6].

In Vietnam, administrative reforms are a part of the reform of the state apparatus to make changes in the constituent parts of the public administration for the state administrative agencies to operate effectively to serve the society and the people. The government's mass mobilization has the role of mobilizing the people to implement this purpose. Currently, mass mobilization work also revolves around the issues of administrative reforms in Vietnam.

Reforming public and transparent administrative procedures with guidelines, policies, socio-economic development programs and projects and the process of settling administrative procedures by local law is an urgent need. In the study "Continuing to innovate and improve the efficiency of the government's advocacy work in the new situation", Truong Thi Mai stated that the focus of innovating mass mobilization work of the state administrative agencies is renewing the Party's mass mobilization work. The implementation of administrative procedure reforms and the process of settling administrative procedures by the law have important implications for strengthening people's trust in the Party and the government and maintaining political stability [7]. In the study "Political system reforms in District 3, Ho Chi Minh City", Nguyen Thi Lan Anh mentioned the mass mobilization of the district government and wards on publicity and transparency of policies, programs, and projects for socio-economic development in the district, revenues and expenditures from the budget, administrative procedures according to the provisions of the law. This study also emphasized the direct connection and dialogue with the people, the reception of people, coordination with the Fatherland Front, and the unions of the district to mobilize the people to perform the tasks of economy, society, security, and defense [8]. In the study on the mass mobilization of the district government on land acquisition in Ho Chi Minh City in the current period, Trinh Thi Phuong mentioned the mass mobilization work of the grassroots government to the people when conducting public works to resolve land acquisition in districts of Ho Chi Minh City today [9]. In the study on the mobilization work of the district People's Committee in Ho Chi Minh City in the current period, Nguyen Hai Quan clarified the position and role of the urban district authorities in mobilizing the people to implement the undertakings and policies of the Party and the laws of the State as well as emphasizing the integrity of the state to win the people's trust [10]. In the scientific research project "The solutions to improve the quality and efficiency of mass mobilization of the state agencies in the current situation", Nguyen Cong Huan focused on clarifying the current situation of the mobilization of the agencies, State authorities in Quang Binh province, and contributing to the variety of the practice of mass mobilization. It mentioned the implementation of administrative procedure reforms, the process of settling administrative procedures according to the regulations coordination with provincial people's unions, and inspection of the implementation of Party's resolutions and directives on mass mobilization [11].

Regarding the problems posed to the government work, in the study "the government's mass mobilization, the practice and the problems raised", Le Mau Lam emphasized administrative reforms and improving working ethics of 
government officials, increasing the satisfaction of the people and units with the service of state agencies and cadres, civil servants and public employees [12]. In the article "Ho Chi Minh's thought on mass mobilization: a manual on mass mobilization work in the new era", Tran Quang Hai emphasized the receipt of people's comments on the management reforms, attitude, and working style of cadres and civil servants of local government agencies [13]. To speed up the process of industrialization and modernization, in the book "Ho Chi Minh's thoughts on mass mobilization work in the reform era in our country today", Tran Dinh Huynh et al said that the cadres performing mass mobilization should have talks with the people, listen to and promptly resolve the people's proposals, frustrations, feelings and legitimate aspirations about administrative reforms [14].

In the process of building socialism, the mass mobilization work of the authorities at all levels has been reformed, consistent with the development situation of the country, contributing to improving people's satisfaction, which is an aspect that authors such as To Lam, Dao Tri Uc mentioned. However, in the book "Ho Chi Minh's thought on the role of the people in the cause of maintaining order and security", To Lam mentioned the effective settlement of administrative tasks such as denouncing letters and complaints, especially in complicated and prolonged cases, not allowing "hot spots" to arise [15]. Also, in the book "The mechanism of the people's supervision for the activities of the Party and State apparatus: Some theoretical and practical issues, Dao Tri Uc upheld the spirit of the rule of law to well implement procedure reforms, public administration, publicity, and transparency of policies to serve the people [16]. In the book "Many issues on mass mobilization work in the current period", Nguyen The Trung showed the values in both theory and practice, bringing resolutions on mass mobilization to life, and mentioning the mass mobilization work of the authorities at all levels. $\mathrm{He}$ suggested that the apparatus of State administrative agencies in charge of mass mobilization should coordinate with the Fatherland Front and mass organizations to mobilize the people to perform economic, social, security and defense tasks [17].

\subsection{Overview on Previous Studies and the Author's Opinion}

It is possible to summarize the contents of previous studies of mass mobilization work as follows: mobilization in the implementation of reforms and transparency of administrative procedures. The above is a summary of achievements and views of previous researchers on the mass mobilization work. It is necessary to draw some preliminary comments on relevant issues to guide the study that the author has selected.

Although no studies has called out and clearly defined the concept of mass mobilization at the district level in administrative reforms, through studies, the authors have described and classified elements of mass mobilization. In general, the previous authors gave us a quite comprehensive and colorful picture of the concept as well as the implementation of mass mobilization work in the current situation. Many of them have also emphasized the issues posing to the government's mass mobilization work on both practical and theoretical aspects.

In our opinion, mass mobilization of the district authorities in administrative reforms in Ho Chi Minh City today includes all activities of organizations, cadres, and civil servants in the system of the district authorities to implement the Party's guidelines, resolutions, and directives, and the State's laws on mobilization work. They aim to propagate, mobilize and organize all the people in the district, related organizations, and forces to form a great force and power of the entire people to successfully implement the Party's guidelines and State's laws on administrative reforms to ensure the successful implementation of the political tasks of the district, promoting ownership and improving the material and spiritual life of the people in the districts of Ho Chi Minh city.

From the practice of more than 30 years of implementing the reform policy, it can be affirmed that the state administrative reform is always a consistent policy, demonstrating the Party's vision in the organization and operation of the reformed state. Therefore, the government's mass mobilization work also adopts specific measures at each stage of the country's development to mobilize the people and the government to reform the state administration following the needs and the management of social development. The mass mobilization work of the authorities of the districts in Ho Chi Minh City has had positive changes: the organization, apparatus, and civil servants of the government from the city to the grassroots have been strengthened; the contents and methods of mass mobilization work of the district government have been reformed, initially promoting the role of the district government in directing and guiding revolutionary action movements of the people in administrative reforms in the city today.

\section{Results and Discussion}

The study has found that the government's mass mobilization plays a very important role in the current city's administrative reforms. Currently, the activities of organizations, cadres, party members, and civil servants in the government system at all levels have been oriented towards the implementation of the Party's undertakings, resolutions and directives, and the State's laws on administrative reforms to improve the material and spiritual life of the people in the districts of the city. The results are as follows:

\subsection{Evaluation of the Government's Mass Mobilization of the Authorities of the Districts in Mobilizing Administrative Procedure Reforms in the City}

Over 5 years of implementing the Conclusion No. 114-KL / TW dated July 14, 2015, of the Party Central Committee's Secretariat (Session XI) on "Improving the efficiency of the mass mobilization work of state agencies at all levels" and 
Directive No. 16 / CT-TTG dated May 16, 2016, of the Prime Minister on "Strengthening and renewing the mass mobilization work in state administrative agencies and governments at all levels in the new situation", the mass mobilization work of the government of Ho Chi Minh City has achieved positive results, especially in the implementation of administrative procedure reforms. The city has focused on reviewing administrative procedures, publicity, and transparency of guidelines, policies, and settlement procedures in all fields for the people to know, ensuring to promote the people's ownership; implementing openly and transparently in all fields, especially those directly related to the rights and interests of the people.

Facing objective and new requirements, Ho Chi Minh City identified administrative reforms as a premise to promote socio-economic development. At the 9th National Party Congress (the term 2010-2015), the city proactively made administrative reforms one of the important breakthrough programs of the term. Next, the city realized that the construction of a new administrative system to replace the outdated methods to better serve the society was an urgent goal, because if the administrative procedures were not well reformed or slowly reformed, the city would lose advantages and administrative procedures would become a great barrier to inhibit the socio-economic development of the locality. Since 2010, the city has built an integrated e-government on the basis of an "electronic one-stop" system, "one-stop-shop" system with many online public services, aiming to simultaneously deploy e-government across many fields. Based on the Action Program of the City Party Committee to implement the Resolution of the 10th City Party Congress on administrative reforms for the 2016-2020 period, the administrative reform implementation plan for the 2016-2020 period and especially the effective implementation of Resolution No. 54/2017 / QH14, dated November 24, 2017, of the National Assembly on piloting specific mechanisms and policies for Ho Chi Minh City development, in 2019, the City People's Committee chose the year of administrative reform with the theme "The breakthrough year of administrative reforms and implementation of Resolution 54 of the National Assembly".

Currently, departments, branches as well as districts of the City have implemented and well implemented the policies of the superiors on administrative reforms at all levels. Every year, in guiding documents, the executive of the People's Committee of Ho Chi Minh City all require: Heads of departments, branches, chairmen of the People's Committees of districts, wards, communes, and towns are responsible for the implementation. Following the documents of their superiors, departments, branches, and localities have developed and announced administrative procedures under their respective jurisdiction. Also, Decision No. 6058 / QDUBND, dated December 28, 2018, issued the Plan to implement administrative reform in the city in 2019, with 7 targets, 44 contents, and key solutions, while promoting the role and responsibility of the head. On March 20, 2019, Official Document No. 985 / UBND-KSTT of the City
People's Committee urgently instructed: "the heads of departments, branches, and presidents of the People's Committees of districts directly instructed the organization and implementation of administrative reforms and application of information technology to serve the building of e-government within the scope of management of the units." The city always emphasized the role and responsibility, as well as determined the success or failure of administrative reforms in agencies and administrative units at all levels depending much on the role of the head of that agency and unit. Therefore, in recent years, the administrative reform activities of Ho Chi Minh City have been very active, constantly being strengthened, and have been recognized and appreciated by the society. With the right guidelines, the serious and scientific implementation process, at the same time, focusing on promoting the role and responsibility of the head for administrative reforms at the agency and unit, the city's administrative reforms have achieved positive results.

From 2002 to 2019, when the administrative procedure reforms were strengthened, the "businesses- City Government dialogue" model was promoted effectively. Through each dialogue, the President of the City People's Committee noted, then directed the heads of agencies and units to promptly remove problems, especially issues related to administrative procedures to create favorable conditions for businesses to invest, produce and do business. To improve the efficiency of administrative reforms, in recent years, the City People's Committee has also integrated into the theme "Responsibility for the head in administrative reforms". This work was both evaluated, reviewed, and it urged the responsibility of the leader in the administrative reforms at agencies and units.

The City People's Committee continues to lead the implementation of Circular No. 06-TT / TU of the Secretariat associated with Directive No. 16-CT / TTG of the Prime Minister on strengthening and renewing mass mobilization of State administrative agencies and governments at all levels in the new situation. It has directed departments, branches, district People's Committees, businesses to effectively implement the authorization scheme, reduce procedures for businesses and people and increase the rate of online public service administrative procedures at levels 3 and 4 and the rate of timely filing of dossiers in each field. It focused on streamlining organizational apparatus, promoting the application of information technology, launching emulation, and implementing 10 projects to welcome the Party Congress at all levels.

State agencies and the authorities in the districts of the city have focused on administrative reforms associated with building awareness and responsibility of cadres, civil servants, and public employees to serve the people. The determination to step up administrative reforms and drastically direct interdisciplinary coordination has shortened time and created positive changes in the settlement of public records. In particular, promoting the application of information technology in publicizing administrative procedures; implementing the "one-stop-shop", 
"interconnected one-stop" mechanism have shortened time for handling documents, created a positive and effective change in the settlement of administrative procedures, contributed to better serve the people.

Citizen reception, complaint and denunciation settlement, direct dialogue with the people are focused on implementation by agencies, units, and localities. At the same time, the city has brought into play quite well the role of the people joining the government in preserving the environment, restoring order to the roadway, preventing and combating crimes and social evils.

To perform well its functions and duties, over the years, the Department of Industry and Trade of the city has always actively raised the responsibility of the head. It is reflected through its drastic direction and applied many solutions to push strongly apply information technology to administrative reforms; promptly remove difficulties and shortcomings in administrative procedures related to investment and business environment for the people and businesses. The head of this agency has also mobilized cadres and civil servants to improve the model of receiving and resolving administrative procedures at the department to improve service quality; step by step change from traditional administrative management to service administration with meeting and supporting the needs of people and businesses.

The Department of Natural Resources and Environment and the offices of Natural Resources and Environment of the districts in the city handle sensitive areas directly related to the people and businesses, especially administrative procedures on land and environment. In the first 10 months of 2019, the Department and offices received more than 570,000 dossiers of all kinds, of which, in the field of land, nearly 501,700 records (an average of 50,170 records/month). To carry out the roles and responsibilities of the head, the Director of the Department organized an ad-hoc inspection of $7 / 12$ offices and committees on the implementation of administrative procedure reforms, thereby, realizing that the problem delayed publication of administrative procedures and delayed appointment processing.

In 2019, the Department of Home Affairs and the interior departments of the districts in the City received 81 complaints and petitions of individuals and organizations on administrative procedures, of which nearly 50 cases of content reflected was the act of delaying, causing trouble, implementing or not complying with the regulations of the cadres and civil servants. Through inspection, the head of the Department promptly rectified, proposed solutions to overcome shortcomings at the same time enhanced the responsibility of the head, raised the sense of service of civil servants, and raised high satisfaction of the people and businesses.

The mass mobilization of the authorities of the districts in mobilizing administrative procedure reforms in the city is reflected in the results of the administrative reform index over the years by departments and districts. It is divided into 02 groups as follows:
In 2017: The results of the PAR Index in 2017 of departments and districts were divided into two groups: Group I: achieving the index results above $80 \%$ including Banking, Department of Finance, Department of Science and Public Technology, Department of Transport, Department of Information and Communication, Department of Justice, Department of Culture, Sports and Tourism, Department of Planning and Investment and 5 Districts, within the City. Group II: achieving PAR Index above $70 \%$ to below $80 \%$ including Department of Home Affairs, Ministry of Health, Department of Industry and Trade, Department of Agriculture and Rural Development, Department of Construction, Department of Education and Training, Department of Natural Resources and Environment, Department of Labor Invalids and Social Affairs and 14 districts under the City. 5 districts still have not acquired the result

In 2018, the results of public administration reform of districts in HCMC were divided into two groups: Group 1 achieving the index results above $80 \%$ including Department of Information and Communication, Financial Department, Ministry of Justice, Department of Industry and Trade, Department of Foreign Affairs, Department of Agriculture and Rural Development, Department of Science and Technology, Department of Home Affairs, Department of Natural Resources and Environment, Department of Education and Training, Department of Labor - Invalids and Social Affairs, and 18 districts in the city. Group II: achieving PAR Index above $70 \%$ to below $80 \%$ including Department of Culture, Sports and Tourism; Department of Transportation; Department of Construction; Department of Planning and investment; Department of Health and 6 districts in the city.

In 2019: The results of the PAR index in 2019 of departments and districts focused on two groups. Group I: achieving the Index result of over $80 \%$, including Department of Finance; Department of Justice; Department of Agriculture and Rural Development; Department of Industry and Trade; Department of Foreign Affairs; Department of Science and Technology; Ministry of Home Affairs; Resource base and environment; Department of Labor - Invalids and Social Affairs; Department of Education and training; Department of Culture, Sports and Tourism; Department of Planning and Investment and 21 districts in the city. Group II: achieving Index results from over $70 \%$ to below $80 \%$, including Department of Construction; Department of Information and communication; Department of Health and Ministry of Transport and 3 districts in the City.

Currently, Ho Chi Minh City is actively implementing the project "Building Ho Chi Minh City to become a smart city for the period 2017-2020, with a vision to 2025 and building an e-government". To achieve this goal, along with the reorganization of the apparatus, administrative units, attracting experts, scientists, the city government always pays special attention to the role and responsibilities of the leader in administrative procedure reforms at the state administrative agencies and units at all levels. 


\subsection{The Assessment of the People's Satisfaction of the Government's Mass Mobilization in Administrative Procedure Reforms}

In the years 2017-2019, the administrative reforms made changes in quality, which was reflected in the following points:

In 2018: According to the survey results, the highest provincial administrative satisfaction index was $95.75 \%$ (District 1), the lowest was $67.70 \%$ (Can Gio district) and the median value was $79.76 \%$. For the rest of the remaining departments and districts, the index of satisfaction of administrative services is in the range of $67.70-79.76 \%$. In 2019: the rate of the people and organizations satisfied with the services of state administrative agencies in general of the City was $82.99 \%$. (The district with the highest satisfaction index at $97.88 \%$ was still in District 1 and the province with the lowest satisfaction index was $69.98 \%$ in Can Gio district).

The City's General Administrative Service Satisfaction Index increased by more than $2 \%$ compared to 2018 . The satisfaction index with 4 factors, namely "access to services, administrative procedures, civil servants, and service results", also increased compared to 2018. However, the satisfaction Index on factors receiving and handling rational opinion comments, reflection, recommendations reduced. 5 out of 24 districts in the city have the satisfaction index of administrative service increased from 1 to $19 \%$.

The people and organizations have positive opinions about the process of providing public administrative services, serving the people and organizations of state administrative agencies in 24 districts under the city. According to the people, organizations surveyed in the City, almost $100 \%$ of the people, organize transactions of public administrative services at the one-stop department; $78.20 \%$ go back $1-2$ times to solve work; $93.80 \%$ received the results on time and soon; $97.55 \%$ do not suffer from troubles or harassment; $98.58 \%$ are not suggested to pay more than fees/charges.

However, the proportion of people and organizations dissatisfied with administrative services in 2019 increased compared to 2018 , from $1.96 \%$ to $2.08 \%$. The proportion of people and organizations satisfied with the process of receiving and processing comments, feedback, and recommendations of state administrative agencies in general in the country in 2019 is lower than in 2018 (74.07\% versus $75.34 \%) .7$ out of 24 districts in the city have the satisfaction index of administrative service decreased from 1 to $12 \%$. The proportion of citizens and organizations that reflect civil servants suggesting to pay more than fees/charges in the locality tends to increase, with the district having the highest rate increasing from $4.30 \%$ in 2017 to $5,01 \%$ in 2018 . The number of people and organizations accessing information on public administrative services via the internet in general in the country is only $7.10 \%$, and that of 24 districts in the city is from $2.50 \%-16.00 \%$. The percentage of people and organizations searching for information about administrative procedures on the internet is even lower, at $4.92 \%$ and from

\section{$3.96 \%$ to $15.04 \%$, respectively.}

\subsection{Discussion}

In addition to the results achieved, the administrative reforms in Ho Chi Minh City still has many limitations and problems that need to be overcome soon. Typically,

in 2019, the city chooses the theme "The year of breakthroughs in administrative reform and implementation of Resolution 54 of the National Assembly", but according to the year-end summary report, the proportion of late dossiers is reduced by $0.29 \%$, equivalent to more than 64,000 records, this is a very high number of late-appointment dossiers (due to the huge number of dossiers received and processed by the City). Which, the most troubles are in the fields related to construction investment using the state budget capital, the appraisal of detailed planning, construction licensing, adjustment of investment projects, acceptance of mechanical construction works. The status of agencies and units has not shown the demand, sympathy with the needs of people and businesses has not seriously implemented apology letters for late-due documents, the rate of not implementing apology letters is quite good, accounting for $7.7 \%$. The public disclosure of all types of dossier procedures in some districts, even at the Office of the City People's Committee, is still slow to announce the processing time for dossiers; service attitude of cadres and civil servants sometimes, sometimes indifferent, harassing, afraid of responsibility. These shortcomings cause frustration for people, lose business and production opportunities for enterprises.

From practice, comments and assessments of delegates at the annual conferences, seminars organized by the People's Council, the People's Committee of Ho Chi Minh City show the cause of the limitation, problems in the administrative procedure reform over the years are because the leadership and direction of the heads of some agencies and units have not been promoted and clearly shown. Specifically, the head has not identified the importance of administrative reform, so the direction and administration have not shown the depth, lack of "breakthrough" character, and are hesitant and afraid of responsibility. That is not to mention the case, despite being decentralized, authorized, but the head still "pushes" the responsibility in coordinating and settling, as well as when there is a job to consult from the superiors. When the head receives a complaint, after verifying that the cadres, civil servants, and officials under the management have an arrogant, authoritarian attitude, causing troubles, harassment towards people and businesses in the task execution process; however, the head does not handle it strictly and thoroughly.

In implementing the policy of promoting e-government, the heads of some agencies and units have not focused on enhancing online public services at level 3 and 4; the guidance and listing of administrative procedures are still heavily "administrative", unclear information, lack of transparency, causing difficulties and time-consuming for people and businesses. The cause of concern for the reform of administrative procedures is still limited and problematic is the role and responsibility of the head in the organization 
and personnel work in some agencies and units are not fair objectively, with local expression; The assessment of staff is still respectful, afraid of collisions, not exemplary, running after achievements and there are still signs of a "ask - give" mechanism.

\section{Conclusion}

In conclusion, the government's mass mobilization of the districts has contributed to the awareness of officials as well as the people about the city's administrative reforms, meeting the people's desire to fully exercise democracy but the law regulations for them, to be able to safely live, do business and contribute to society without being harassed, to be provided with quality public services with openness and transparency of administrative procedures and openly and transparently in the activities of civil servants and administrative officials when dealing with issues related to the people, specifically:

Firstly, the study clarified the theoretical views on the long-term and continuous process of administrative reforms to improve organizational efficiency, improve administrative regimes and modes. The mobilization of the government should focus on the content of administrative reforms of the Government to mobilize the people, departments, branches, and unions to perform well.

Secondly, the study showed the current situation of the mass mobilization work of the districts and the assessment of the people's satisfaction on administrative reforms. The study showed the problems raised by the district authorities about mobilizing the people as well as other organizations to implement this issue, such as awareness and actions of the district itself, the power of districts on administrative reforms, promoting the building of "Government of creation, integrity, Government of service", administrative procedure reforms in some areas continued to have positive changes, the business investment environment index was significantly improved; the review, reorganization, and consolidation of organizational apparatus, streamlining staffing in ministries, branches and localities have had positive results; administrative disciplines have been tightened; the application of information technology has improved the service quality of district administrative agencies.

\section{References}

[1] Doan Trong Truyen (1999). General Administration, Hanoi: National Political Publishing House.

[2] Ministry of Home Affairs (2010). Document for fostering civil servants implementing the administrative reform at the provincial level. Hanoi: National Political Publishing House.

[3] Communist Party of Vietnam (1986). Document of the 6th National Congress Implementing a major reform of the organizational apparatus of state agencies."

[4] Administrative Academy (2013). Public Administration Hanoi: Political administration publishing House.

[5] Party Central Committee Session X: Resolution of the 5th Conference of the Central Committee (2007) Bn promoting administrative reform, improving the effectiveness and efficiency of management of the state apparatus"

[6] The Party Central Committee, Session XII: Resolution No. 18$N Q$ / TW Some issues on continuing to renew, organizing the apparatus of a streamlined political system, effective and effective operation"

[7] Truong Thi Mai (2020), Continuing to innovate and improve the efficiency of the government's mobilization work in the new situation, Journal of Front line.

[8] Nguyen Thi Lan Anh (2018). Master thesis: The renovation of mass mobilization work of the political system in District 3, Ho Chi Minh City.

[9] Trinh Thi Phuong (2018) Master thesis: The mass mobilization work of the district government in land acquisition in Ho Chi Minh City in the current period.

[10] Nguyen Hai Quan (2019). The mass mobilization work of the District People's Committee in Ho Chi Minh City in the current period.

[11] Nguyen Cong Huan (2017). Provincial scientific research project Solutions to improve the quality and efficiency of mobilization work of state agencies in the current situation.

[12] Le Mau Lam (2019). Government mass mobilization: practice and problems. Nhan Dan newspaper, January 4, 2019.

[13] Tran Quang Hai (2009). Ho Chi Minh's thought on mass mobilization work: A handbook on mass mobilization work in the new era. Communist Review, vol. 35.

[14] Tran Dinh Huynh et al. (2013). Ho Chi Minh's Thought on mobilization work in the reform era in our country today, Hanoi: Labor - Society Publishing House.

[15] To Lam (2016). Ho Chi Minh's Thought on the role of the people in the cause of maintaining order and security. Hanoi: National Political Publishing House.

[16] Dao Tri Uc (2010). The people's monitoring mechanism for the activities of the Party and State apparatus: A number of theoretical and practical issues. Hanoi: National Political Publishing House.

[17] Nguyen The Trung (2015). Some issues about the mass mobilization work in the current period. Hanoi: National Politics- The Truth Publishing House. 